\title{
Pengaruh Permainan Sains Terhadap Perkembangan Kecerdasan Logika Matematika Anak Usia Dini
}

\author{
Siti Marli'ah \\ Univesitas PGRI Ronggolawe \\ sitiemarliah@gmail.com
}

\begin{abstract}
Abstrak
Penelitian ini bertujuan untuk menganalisis pengaruh permainan sains terhadap perkembangan kecerdasan logika matematika pada anak usia dini. Penelitian ini merupakan jenis penelitian eksperimen yang menggunakan bentuk rancangan nonequivalent control group design. Penelitian ini dilaksanakan di TK Islam Insan Kamil Tuban dengan subyek penelitian sebanyak 40 anak yang dibagi menjadi kelompok kontrol dan kelompok eksperimen. Data penelitian dikumpulkan dengan teknik observasi dan dokumentasi. Analisis data menggunakan uji ANOVA atau uji F. Hasil penelitian menunjukkan bahwa secara garis besar permainan sains berpengaruh terhadap perkembangan kecerdasan logika matematika anak. Hal ini terbukti dengan adanya perbedaan hasil kemampuan logika matematika antara kelompok eksperimen yaitu sebesar $70 \%$ dan kelompok kontrol sebesar $58,75 \%$. Selanjutnya disarankan untuk guru dan lembaga PAUD agar menerapkan kegiatan bermain sains sebagai salah satu alternatif kegiatan untuk menstimulasi kecerdasan logika matematika anak.
\end{abstract}

Kata Kunci: Permainan Sains, Kecerdasan Logika Matematika

\begin{abstract}
This study aims to analyze the influence of science playing on the development of mathematical logic intelligence in early childhood. This research is a type of experimental research using nonquivalent control group design. This research was conducted at TK Islam Insan Kamil Tuban with research subject of 40 children divided into control group and experiment group. The research data was collected by observation and documentation technique. Data analysis using ANOVA test or F test. The results showed that the science playing has an effect on the development of the mathematical logic intelligence of children. This is evidenced by the difference of mathematical logic result between experimental group that is equal to $70 \%$ and control group equal to $58,75 \%$. Furthermore, it is recommended for teachers and institutions of early childhood to apply science play activities as an alternative of learning activities to stimulate the mathematical logic intelligence of children.
\end{abstract}

Keywords: Science Play, Mathematical Logic Intelligence 


\section{PENDAHULUAN}

Kecerdasan merupakan kemampuan tertinggi yang dimiliki manusia. Tingkat kecerdasan dapat membantu seseorang dalam menghadapi berbagai masalah yang muncul dalam kehidupannya. Kecerdasan yang sudah dimiliki sejak manusia lahir dapat dikembangkan secara terus menerus hingga dewasa. Pengembangan kecerdasan ini akan lebih baik jika dilakukan sejak anak dilahirkan melalui pemberian berbagai stimulus melalui kelima panca inderanya.

Kecerdasan merupakan ungkapan dari cara berpikir seseorang yang dapat dijadikan modalitas dalam belajar. Kecerdasan bagi seseorang memiliki manfaat yang besar bagi dirinya sendiri dan juga bagi pergaulannya di masyarakat. Tingkat kecerdasan yang tinggi pada seseorang akan membawanya pada kehidupan sosial yang lebih baik, karena ia mampu berkiprah dalam menciptakan hal-hal baru yang bersifat fenomenal sehingga lebih dihargai di masyarakat.

Pandangan terkini menunjukkan bahwa manusia memiliki berbagai kecerdasan yang terdapat dalam dirinya. Semiawan menyatakan bahwa adanya perbedaan individu dalam hal kemampuan kemampuan bawaannya menyebabkan setiap individu memilikji satu atau dua kecerdasan yang dapat diunggulkan dari dalam dirinya. Keunggulan yang khusus tersebut apabila distimulasi secara optimal akan dapat menjadi keunggulan bagi anak tersebut ${ }^{1}$.

Gardner dalam bukunya Multiple Intelligences, menyatakan terdapat delapan kecerdasan pada manusia yaitu: kecerdasan linguistik/verbal/bahasa, kecerdasan matematis logis, kecerdasan visual/ruang/spasial, kecerdasan musikal/ritmis, kecerdasan kinestetik jasmani, kecerdasan interpersonal, kecerdasan intrapersonal, dan kecerdasan naturalis. Diantara delapan kecerdasan yang diungkapkan oleh Gardner, kecerdasan logika matematika sering dipandang dan dihargai lebih tinggi dari jenis-jenis kecerdasan lainnya. Kecerdasan ini dicirikan sebagai kemampuan yang dimiliki otak kiri atau berkaitan dengan kemampuan kognitif dan intelektual anak.

Kecerdasan logika matematika sangat penting untuk dikembangakan sejak dini mengingat pada masa usia dini perkembangan otak mengalami lompatan dan berjalan demikian pesat. Hal ini sesuai dengan penelitian Bloom bahwa " $50 \%$ dari potensi intelektual anak sudah terbentuk di usia 4 tahun kemudian mencapai sekitar $80 \%$ pada usia 8 tahun" ${ }^{2}$. Selain alasan tersebut, mengembangkan kecerdasan logika matematika sejak usia dini juga didasarkan pada pernyataan bahwa pada dasarnya setiap anak dianugerahi kecerdasan logika matematika. Hal ini bisa dilihat pada sejak usia balita, anak gemar bereksplorasi untuk memenuhi rasa ingin tahunya seperti menjelajah setiap sudut, mengamati benda-benda yang unik baginya, senang mengutak-atik benda serta melakukan uji coba. Seperti bagaimana jika kakiku masuk kedalam ember penuh berisi air atau penasaran menyusun puzzle. Mereka juga sering bertanya tentang berbagai fenomena dan menuntut penjelasan logis dari tiap pertanyaan yang diajukan. Selain itu anak juga suka mengklasifikasikan berbagai benda berdasarkan warna, ukuran, jenis dan lain-lain serta gemar berhitung. Anak yang memiliki kecerdasan logika matematika yang tinggi cenderung menyenangi kegiatan menganalisis dan mempelajari sebab akibat terjadi sesuatu. Ia menyenangi berfikir secara konseptual, misalnya menyusun hipotesis, mengadakan kategorisasi dan klasifikasi terhadap apa yang dihadapinya. Anak semacam ini cenderung menyukai aktivitas berhitung dan memiliki kecepatan tinggi dalam menyelesaikan problem matematika.

Mengenalkan konsep logika matematika pada anak usia dini dapat dilakukan melalui kegiatan sehari-hari dari lingkungan sekitar anak tanpa paksaan dan tekanan serta melalui berbagai bentuk permainan. Banyak jenis permainan eksplorasi yang bisa mengasah kecerdasan logika matematika anak, salah satunya adalah permainan sains. Permainan sains memungkinkan anak melakukan eksplorasi terhadap berbagai benda, baik benda hidup

\footnotetext{
${ }^{1}$ Semiawan, Conny. 2002. Belajar dan Pembelajaran dalam Taraf Usia Dini. (Jakarta: Prennhalindo, 2002), 125-127

${ }^{2}$ Suyanto, S. Pembelajaran Untuk Anak TK. (Jakarta: Depdiknas, 2005), 6.
} 
maupun benda tak hidup yang ada disekitarnya.Anak belajar menemukan gejala benda dan gejala peristiwa dari benda-benda tersebut. Pernyataan tersebut sejalan dengan pendapat Sujiono, dkk, bahwa permainan sains pada anak bertujuan agar anak mampu secara aktif mencari informasi tentang apa yang ada di sekitarnya. Sains juga melatih anak menggunakan lima inderanya untuk mengenal berbagai gejala benda dan gejala peristiwa dengan dilatih untuk melihat, meraba, membau, merasakan dan mendengar. Semakin banyak keterlibatan indera dalam belajar, anak akan semakin memahami apa yang dipelajari ${ }^{3}$. Melalui proses sains, anak dapat melakukan percobaan sederhana dan percobaan ini akan melatih anak menghubungkan sebab dan akibat dari suatu perlakuan sehingga melatih anak berpikir logis dan rasional. Dengan demikian sains dapat mengembangkan kemampuan intelektual anak. Banyak manfaat yang bisa diperoleh jika anak sejak dini diperkenalkan dengan kegiatan sains. Sains akan melatih anak untuk bereksperimen dengan melakukan beberapa percobaan sehingga memperkaya wawasannya untuk selalu ingin mencoba. Artinya sains dapat mengarahkan dan mendorong anak menjadi orang yang kreatif dan penuh inisiatif. Permainan sains juga membiasakan anak-anak untuk mengikuti tahap-tahap eksperimen dan tak boleh menyembunyikan suatu kegagalan. Dalam hal ini sains dapat melatih mental positif, berpikir logis dan urut (sistematis). Permainan sains juga dapat melatih anak untuk bersikap cermat karena anak harus mengamati, menyusun prediksi, menerapkan konsep ukuran, dan mengambil keputusan.

Namun pada kenyataannya pembelajaran untuk mengasah kecerdasan logika-matematika anak di lembaga pendidikan TK masih kurang optimal sehingga mengakibatkan kecerdasan logika-matematika anak masih rendah. Terbukti dari hasil observasi pada anak kelompok A di TK Islam Insan Kamil kabupaten Tuban, banyak anak yang mengalami kesulitan dalam memahami konsep logika-matematika melalui aktivitas berhitung yang diajarkan, kesulitan dalam memahami konsep benda yang jumlahnya lebih banyak, lebih sedikit, sama banyak, kesulitan dalam memahami konsep bilangan, serta kesulitan mengungkapkan hubungan sebab akibat maupun asal mula terjadinya sesuatu pada kegiatan percobaan sederhana.

Hal lain yang ditemui di TK Islam Insan Kamil kabupaten Tuban adalah pelaksanaan pembelajaran yang monoton dimana anak hanya menjadi objek dalam proses pembelajaran dan kurangnya kreativitas guru dalam menggunakan pendekatan pembelajaran yang digunakan dalam memberikan materi pembelajaran kepada anak. Pendekatan yang digunakan dalam memberikan materi ajar untuk mengembangkan kecerdasan logikamatematika masih bersifat konvensional, formal dan lebih sering menggunakan LKA dengan metode ceramah. Pengembangan kecerdasan logika matematika dengan pemberian tugas menggunakan lembar kerja anak, terkesan kaku, kurang menyenangkan, dan kurang memberikan kesempatan kepada anak untuk berinteraksi dengan benda-benda konkret. Anak belum diberikan kesempatan untuk terlibat langsung dalam suatu aktivitas seperti, mengamati, mengklasifikasi, menyimpulkan dan mengkomunikasikan. Anak hanya sebagai penonton dan pendengar, yang kemudian anak diberikan lembar kerja dan mengerjakan kegiatan seperti penjelasan guru. Anak tidak mendapat kesempatan untuk ikut aktif terlibat dalam proses menemukan hasil.

Permainan sains pada anak usia dini adalah mengembangkan proses berpikir anak, dimana anak belajar untuk memahami fenomena, menjawab pertanyaan, menemukan informasi yang lebih banyak tentang sesuatu dan mempertanyakan kesimpulan yang diperoleh oleh anak lain secara logis. Hal-hal tersebut tidak dapat digantikan oleh fungsi buku kegiatan yang menjadi subyek utama dalam kegiatan anak. Anak-anak kurang mendapat kesempatan untuk melakukan proses berpikir ilmiah, karena hanya menyelesaikan tugas sesuai petunjuk dan penjelasan guru. Sehingga perkembangan kemampuan logika matematika anak belum optimal.

Berdasarkan uaraian latar belakang di atas, maka peneliti tertarik untuk melakukan penelitian dengan judul "Pengaruh Permainan Sains terhadap Perkembangan Kecerdasan

\footnotetext{
${ }^{3}$ Sujiono, N. Tampiomas, E. Zainal, R. Metode Pengembangan Kognitif. (Jakarta: Depdiknas, 2007), 12.3
} 
Logika Matematika Anak usia Dini" Penelitian ini dilaksanakan pada anak kelompok A di TK Islam Insan Kamil kabupaten Tuban. Alasan peneliti melaksanakan penelitian di TK Islam Insan Kamil kabupaten Tuban karena pembelajaran yang diterapkan dalam meningkatkan kecerdasan logika-matematika belum pernah menerapkan permainan sains. Materi pembelajaran lebih menekankan pada kegiatan baca tulis hitung (calistung) secara konvensional sehingga kecerdasan logika-matematika anak kurang optimal perkembangannya. Hal lain yang menjadi alasan peneliti adalah masih sangat jarang dilaksanakan penelitian di TK Islam Insan Kamil kabupaten Tuban, terutama penelitian yang menyangkut kecerdasan logika-matematika.

\section{KAJIAN LITERATUR}

\section{A. Kecerdasan Logika Matematika}

Kecerdasan Logika-matematika didifinisikan kemampuan menggunakan angka dengan baik dan melakukan penalaran yang benar. Kemampuan ini meliputi kemampuan menyelesaikan masalah dan menciptakan sesuatu dengan angka dan penalaran ${ }^{4}$. Kecerdasan ini melibatkan keterampilan mengolah angka dan menggunakan logika atau akal sehat. Kecerdasan logika matematika mencakup tiga bidang yang saling berhubungan yakni matematika, ilmu pengetahuan (sains) dan logika ${ }^{5}$. Sedangakan menurut Gardner bahwa kecerdasan logika-matematika didefinisikan sebagai kemampuan untuk menangani relevansi atau argumentasi serta mengenali pola dan urutan ${ }^{6}$. Saifullah menyatakan bahwa kecerdasan logika matematika adalah kemampuan menggunakan angka dengan baik dan melakukan penalaran yang benar ${ }^{7}$. Pendapat tersebut sejalan dengan ungkapan Lwin yang menyatakan bahwa kecerdasan logika matematika adalah kemampuan untuk menangani bilangan, pengkategorian, perhitungan, pola dan pemikiran logis dan ilmiah ${ }^{8}$. Sementara Suyadi berpendapat bahwa Kecerdasan logika-matematika adalah kemampuan untuk menangani bilangan dan perhitungan, pola pikir logis dan ilmiah ${ }^{9}$.

Anak-anak yang cerdas dalam logika matematika cenderung terus bertanya dan ingin tahu tentang sebab-akibat suatu peristiwa atau gejala dilingkungannya, seperti mengapa ada petir, banjir, gempa bumi, dan gunung meletus. Mereka juga cenderung memilih permainan yang memerlukan pemikiran dan strategi.

Perkembangan kecerdasan logika matematika pada anak dipengaruhi oleh beberapa faktor berikut: (1) fakor keturunan, setiap anak memiliki gen pembawa kecerdasan dengan kadar yang berbeda-beda, (2) lingkungan, lingkngan memiliki peran yang sangat besar dalam mengembangkan kecerdasan anak karena anak banyak belajar dengan cara berinteraksi dengan lingkungan, (3) asupan nutrisi pada makanan, dan (4) aspek kejiwaan, kondisi emosi bernilai penting dalam menumbuhkan bakat dan minat anak sehingga berpengaruh pada tingkat kecerdasan anak.

Pengembangan kecerdasan logika matematika pada anak usia dini mengacu pada pedoman kurikulum PAUD, diantaranya kurikulum yang tertuang dalam Peraturan Menteri Pendidikan Nasional No. 58 tahun 2009 tentang Standar Pendidikan Anak Usia Dini. Tingkat pencapaian perkembangan logika-matematika dengan lingkup kemampuan logikamatematika anak usia 4-6 tahun ${ }^{10}$ sesuai kurikulum tersebut dirumuskan pada tabel berikut:

\footnotetext{
${ }^{4}$ Amstrong, Thomas. Sekolah Sang Juara: Menerapkan Multiple Intelligence di Dunia Pendidikan $2^{\text {nd }}$ . Terjemahan. (Bandung: Kaifa, 2002), 2

${ }^{5}$ Campbell, linda, Bruce Campbell, dan Dee Dickinson. Teching and Learning through Multiple Intelligence. Terjemahan. Depok: Inisiasi Press, 2002), 45

${ }^{6}$ Gardner, Howard. Kecerdasan Majemuk. (Batam: Interaksara, 2003), 15

${ }^{7}$ Saifullah. Mencerdaskan Anak (Mengoptimalkan Kecerdasan Intelektual, Emosi dan Spiritual Anak). (Jombang: Lintas Media, 2004), 30

${ }^{8}$ Lwin, May, dkk. How to Multiply Your Child's Intelligence. Yogyakarta: Penerbit Indeks, 2008), 43

${ }^{9}$ Suyadi. Psikologi Belajar Pendidikan Anak Usia Dini. Yogyakarta: PT Pustaka Intan Madani, 2010), 154

${ }^{10}$ Peraturan Menteri Pendidikan Nasional no 58 tahun 2009, Standar PAUD
} 
Tabel 1 Tingkat Pencapaian Perkembangan Anak Usia Dini

\begin{tabular}{|c|c|c|}
\hline \multirow{2}{*}{$\begin{array}{c}\text { Lingkup } \\
\text { Perkembangan }\end{array}$} & \multicolumn{2}{|c|}{ Tingkat Pencapaian Perkembangan } \\
\hline & Usia $4-<5$ Tahun & Usia $5-6$ tahun \\
\hline $\begin{array}{l}\text { Konsep sains } \\
\text { sederhana }\end{array}$ & $\begin{array}{l}\text { 1. Mengenal gejala sebab } \\
\text { akibat yang terkait dengan } \\
\text { dirinya } \\
\text { 2. Mengenal konsep } \\
\text { sederhana dalam } \\
\text { kehidupan sehari-hari }\end{array}$ & $\begin{array}{l}\text { 1. Menunjukkan aktivitas } \\
\text { yang bersifat eksploratif } \\
\text { dan menyelidik (seperti apa } \\
\text { yang terjadi ketika air } \\
\text { ditumpahkan) } \\
\text { 2. Mengenal sebab akibat } \\
\text { tentang lingkungannya }\end{array}$ \\
\hline $\begin{array}{l}\text { Konsep bentuk, warna, } \\
\text { ukuran, dan pola }\end{array}$ & $\begin{array}{l}\text { 1. Mengklasifikasikan benda } \\
\text { berdasarkan bentuk dan } \\
\text { warna. } \\
\text { 2. Mengklasifikasikan benda } \\
\text { ke dalam kelompok yang } \\
\text { sama atau kelompok yang } \\
\text { sejenis atau kelompok } \\
\text { yang. berpasangan dengan } \\
2 \text { variasi } \\
\text { 3engenal pola AB-AB } \\
\text { dan ABC-ABC. } \\
\text { 4. Mengurutkan benda } \\
\text { berdasarkan } 5 \text { seriasi } \\
\text { ukuran atau warna. }\end{array}$ & $\begin{array}{l}\text { 1. } \begin{array}{l}\text { Mengenal perbedaan } \\
\text { berdasarkan ukuran "lebih } \\
\text { dari", "kurang dari", atau } \\
\text { "paling/ter". }\end{array} \\
\text { 2. Mengklasifikasikan benda } \\
\text { berdasarkan warna, bentuk, } \\
\text { dan ukuran (3 variasi) } \\
\text { 3. Mengklasifikasikan benda } \\
\text { yang lebih banyak ke } \\
\text { dalam kelompok yang } \\
\text { sama atau kelompok yang } \\
\text { sejenis, atau kelompok } \\
\text { berpasangan yang lebih } \\
\text { dari } 2 \text { variasi. } \\
\text { 4. Mengenal pola ABCD- } \\
\text { ABCD } \\
\text { 5. Mengurutkan benda } \\
\text { berdasarkan ukuran dari } \\
\text { yang paling kecil ke paling } \\
\text { besar dan sebaliknya. }\end{array}$ \\
\hline $\begin{array}{l}\text { Konsep bilangan, } \\
\text { lambang bilangan, dan } \\
\text { huruf }\end{array}$ & $\begin{array}{l}\text { 1. Mengetahui konsep } \\
\text { banyak dan sedikit. } \\
\text { 2. Membilang banyak benda } \\
\text { satu sampai sepuluh. } \\
\text { 3. Mengenal konsep } \\
\text { bilangan. } \\
\text { 4. Mengenal lambang } \\
\text { bilangan. } \\
\text { 5. Mengenal lambang huruf. }\end{array}$ & $\begin{array}{l}\text { 1. Menyebutkan lambang } \\
\text { bilangan satu sampai } \\
\text { sepuluh. } \\
\text { 2. Mencocokkan bilangan } \\
\text { dengan lambang bilangan } \\
\text { 3. Mengenal berbagai macam } \\
\text { lambang huruf vokal dan } \\
\text { konsonan }\end{array}$ \\
\hline
\end{tabular}

\section{B. Permainan Sains}

Permainan sains pada anak usia dini merupakan kegiatan belajar yang menyenangkan dan menarik yang dilaksanakan sambil bermain melalui pengamatan, penyelidikan, dan percobaan untuk mencari tahu atau menemukan jawaban tentang kenyataan yang ada di dunia sekitar ${ }^{11}$. Pernyataan ini sejalan dengan yang diungkapkan oleh Suyanto, bahwa

${ }^{11}$ Sujiono, N. Tampiomas, E. Zainal, R. Metode Pengembangan Kognitif. (Jakarta: Depdiknas, 2007), 12.3 
permainan sains pada anak merupakan kegiatan yang memungkinkan anak untuk melakukan eksplorasi terhadap berbagai benda di sekitarnya ${ }^{12}$.

Dari pernyataan-pernyataan di atas, dapat disimpulkan bahwa permainan sains pada anak adalah proses atau cara untuk memahami dan mencari tahu serta menemukan jawaban tentang kenyataan yang ada di sekitar melalui pengamatan, penyelidikan, dan percobaan yang dilakukan dengan menyenangkan dan menarik melalui kegiatan bermain. Sehingga lebih lanjut dapat dikatakan bahwa permainan sains pada anak pada hakikatnya adalah mengembangkan kemampuan dalam melakukan serangkaian proses sains, yaitu kemampuan dalam mengamati, mengklasifikasi, memprediksi, bereksperimen, dan mengkomunikasikan hasil penemuan untuk memenuhi rasa keingintahuannya.

Materi permainan sains menurut pendapat Dodge mengungkapkan bahwa kegiatan sains terdiri dari physical science, life science, serta bumi dan sekitarnya. Dimana physical science terdiri dari objek-objek yang dapat dieksplor, karena anak dapat belajar tentang berat, bentuk, ukuran, warna, dan suhu. Life Science menceritakan tentang prosesnya seperti mempelajari tentang proses pertumbuhan tanaman dan kehidupan binatang ${ }^{13}$.

Secara umum permainan sains di lembaga Taman Kanak-kanak bertujuan agar anak mampu secara aktif mencari informasi tentang apa yang ada di sekitarnya untuk memenuhi rasa ingintahu anak melalui pengamatan, penyeledikan, dan percobaan. Sedangkan secara khusus permainan sains di Taman Kanak-kanak bertujuan agar anak memiliki kemampuan dalam hal berikut: (1) mengamati perubahan yang terjadi disekitarnya, (2) melakukan percobaan sederhana, (3) melakukan kegiatan membandingkan, memperkirakan, mengklasifikasi, serta mengkomunikasikan tentang hasil pengamatan, dan (4) meningkatkan kreativitas ${ }^{14}$.

Leeper juga menyampaikan bahwa permainan sains pada anak mempunyai tujuan sebagai berikut: (1) agar anak memiliki kemampuan memecahkan masalah yang dihadapinya melalui pengguanaan metode sains, sehingga anak-anak terbantu dan menjadi terampil dalam menyelesaikan berbagai hal yang dihadapi, (2) agar anak-anak memiliki sikap ilmiah. Hal ini mendasar misalkan, tidak cepat-cepat dalam mengmabil keputusan, dapat melihat segala sesuatu dari berbagai sudut pandang, berhati-hati terhadapa informasi-informasi yang diterimanya serta bersifat terbuka, (3) agar anak-anak mendapatkan pengetahuan dan informasi ilmiah, dan (4) agar anak-anak menjadi lebih berminat dan tertarik untuk menghayati sains yang berada dan ditemukan di lingkungan dan alam sekitarny $\mathrm{a}^{15}$.

Adapun menurut Nugraha (2005: 30-32), tujuan permainan sains pada anak dibagi menjadi tiga, yaitu: (1) pengenalan dan penguasaan fakta, konsep, prinsip, teori maupun aspek-aspek lain yang terkait dengan hal-hal yang ditemukan dalam bidang sains itu sendiri, (2) pada dimensi proses, permainan sains diarahkan pada penguasaan ketrampilanketrampilan yang diperlukan dalam menggali dan mengenal sains, dan (3) pada dimensi sikap, permainan sains dimaksudkan untuk mengembangkan pribadi dan karakter anak ${ }^{16}$.

Permainan sains pada anak usia dini merupakan salah satu hal yang penting karena mempunyai multi manfaat. Beberapa manfaat permainan sains pada anak usia dini adalah sebagai berikut: (1) eksplorasi dan investigasi, yaitu kegiatan untuk mengamati dan menyelidiki objek serta fenomena alam, (2) mengembangkan ketrampilam proses dasar, seperti melakukan pengamatan, mengukur, mengkomunikasikan hasil pengamatan dan sebagainya, serta (3) mengembangkan rasa ingin tahu, rasa senang, dan melakukan kegiatan inkuiri atau penemuan serta untuk memahami pengetahuan tentang berbagai benda baik ciri,

\footnotetext{
12 Suyanto, S. Pembelajaran Untuk Anak TK. (Jakarta: Depdiknas, 2005), 83

${ }^{13}$ Nugraha, A. Pengembangan Pembelajaran Sains Anak Usia Dini. (Jakarta: Danendra, 2005), 4

${ }^{14}$ Sujiono, N. Tampiomas, E. Zainal, R. Metode Pengembangan Kognitif. (Jakarta: Depdiknas, 2007), 145

${ }^{15}$ Nugraha, A. Pengembangan Pembelajaran Sains Anak Usia Dini. (Jakarta: Danendra, 2005), 28-29

${ }^{16}$ Ibid, 30-32
} 
struktur, maupun fungsi ${ }^{17}$. Sedangkan menurut Nugraha permainan sains mempunyai manfaat dan nilai bagi perkembangan anak, diantaranya: (1) perkembangan kognitif, melalui permainan sains anak dapat meningkatkan kemampuan mengingat dan mengendapkan ilmu yang diperolehnya, serta dapat menggunakan konsep yang dipelajarinya melalui lingkungan belajarnya, (2) kemampuan afektif, permainan sains menjadikan lingkungan belajar yang menyenangkan, bermakna menyentuh anak. Sehingga dapat mengembangkan afeksi anak secara positif, (3) kemampuan psikomotorik, ketika melakukan kegiatan sains akan berdampak pada meningkatnya kemampuan motorik anak, (4) pengembangan ketrampilam berpikir, permainan sains akan meragsang anak untuk memunculkan pertanyaan-pertanyaan menakjubkan, dan melalui pengalaman langsung intelektual anak akan menjadi terlatih, serta berpikir kritis, (5) pengembangan aktualisasi dan kesiapan anak dalam mengisi kehidupannya, permainan sains pada anak membantu menyiapkan anak sebagai investasi dan sumber daya manusia masa depan yang cerah, dan (6) perkembangan religius, permainan sains dapat meningkatkan kesadaran religius dan apresiasi yang semakin tinggi tentang keberadaan Sang Pencipta serta untuk menumbuhkan rasa bersyukur dan memuliakanNya ${ }^{18}$.

\section{Permainan Sains untuk Mengoptimalkan Kecerdasan Logika Matematika Anak Usia Dini}

Kegiatan sains memungkinkan anak melakukan berbagai kegiatan eksplorasi terhadap berbagai benda baik benda yang hidup maupun benda yang tidak hidup, sains dapat juga melatih anak untuk secara optimal menggunakan lima inderanya untuk mengenal berbagai gejala peristiwa disekitar anak. Dalam hal ini anak dapat dilatih untuk melihat, meraba, membau, merasakan, dan mendengar. Sehingga secara optimal mempergunakan 5 indera pengetahuan yang akan diperoleh anak akan berguna sebagai modal untuk berpikir pada proses selanjutnya. Melalui permainan sains, anak dapat melakukan berbagai percobaan sederhana dengan benda yang ada disekitar anak, percobaan tersebut dan dapat melatih anak menghubungkan sebab dan akibat dari suatu perlakuan, sehingga melatih anak untuk dapat berpikir secara logis.

Anak usia 5-6 tahun masih sulit menghubungkan sebab akibat yang tidak terlihat secara langsung karena pikiran mereka yang bersifat transduktif, anak tidak dapat menemukan secara langsung hubungan sebab akibat yang tidak terlihat secara langsung, namun jika hubungan sebab akibat tersebut dapat secara langsung terlihat hal ini akan memudahkan anak untuk mengetahui adanya hubungan sebab akibat, oleh karena itu diperlukan kegiatan pembelajaran sains diperlukan karena sains kaya akan kegiatan yang melatih anak untuk menghubungkan sebab akibat.

Kegiatan permainan sains memungkinkan anak untuk memanipulasi dan mengamati sehingga menemukan jawaban atas hubungan sebab akibat dengan melibatkan aspek fisik dan penalarannya ketika anak mencari tahu tentang suatu materi atau media. Hal ini sesuai dengan pernyataan Chille yang menjelaskan bahwa sebisa mungkin mereka mendapatkan pengetahuan itu dari bahan atau media itu sendiri, yaitu dengan cara mengamati langsung, apabila mereka membuat suatu hubungan antara materi atau bahan, maka mereka sebenarnya belajar tentang logika atau penalaran ${ }^{19}$. Sejalan dengan pendapat tersebut, Suyanto berpendapat bahwa pengetahuan yang diperoleh melalui percobaan sederhana akan berguna sebagai modal berpikir. Percobaan tersebut melatih anak menghubungkan sebab dan akibat dari suatu perlakuan sehingga melatih peserta didik berpikir logis ${ }^{20}$.

Dalam permainan sains anak juga berlatih menggunakan alat ukur non standar, seperti jengkal, depa, atau kaki. Selanjutnya peserta didik berlatih menggunakan alat ukur standar.

\footnotetext{
${ }^{17}$ Suyanto, S. Pembelajaran Untuk Anak TK. (Jakarta: Depdiknas, 2005), 159

${ }^{18}$ Nugraha, A. Pengembangan Pembelajaran Sains Anak Usia Dini. (Jakarta: Danendra, 2005),37

${ }^{19}$ Sujiono, N. Tampiomas, E. Zainal, R. Metode Pengembangan Kognitif. (Jakarta: Depdiknas, 2007), 80

${ }^{20}$ Suyanto, S. Pembelajaran Untuk Anak TK. (Jakarta: Depdiknas, 2005), 84
} 
Dengan demikian anak secara bertahap berlatih menggunakan satuan yang memudahkan anak untuk mengenal konsep ukuran secara matematis, logis, dan rasional. Sehingga dapat disimpulkan bahwa kegiatan bermain sains juga mengembangkan kemampuan matematika anak. Pernyataan tersebut sesuai dengan pendapat Sujiono, dkk., (2007: 156) yang menyatakan bahwa kegiatan bermain sains dapat mengembangkan kemampuan sains sederhana yaitu kemampuan eksperimen, observasi, klasifikasi, mengukur, perkiraan, dan komunikasi ${ }^{21}$.

\section{METODE PENELITIAN}

Pendekatan yang digunakan dalam penelitian ini adalah pendekatan kuantitatif. Metode penelitian kuantitatif dapat diartikan sebagai metode penelitian yang berdasarkan pada filsafat positivism, digunakan untuk meneliti pada populasi atau sampel tertentu, teknik pengambilan sampel pada umumnya dilakukan secara random, pengumpulan data menggunakan instrumen penelitian, analisis data bersifat kuantitatif/ statistik dengan tujuan untuk menguji hipotesis yang telah ditetapkan ${ }^{22}$.

Rancangan penelitian yang digunakan adalah penelitian eksperimen, yaitu penelitian yang dilakukan terhadap variabel yang data-datanya belum ada, sehingga perlu dilakukan proses manipulasi melalui pemberian perlakuan tertentu terhadap subyek penelitian yang kemudian diamati dan diukur dampaknya. Penelitian eksperimen merupakan penelitian yang sistematis, logis, dan teliti di dalam melakukan kontrol terhadap kondisi. Dalam penelitian eksperimen peneliti memanipulasikan sesuatu stimuli, perlakuan atau kondisi-kondisi eksperimental, kemudian mengobservasi pengaruh yang diakibatkan oleh adanya perlakuan atau manipulasi tersebut. Dengan demikian metode penelitian eksperimen dapat diartikan sebagai metode penelitian yang digunakan untuk mencari pengaruh perlakuan tertentu terhadap yang lain dalam kondisi yang terkendalikan ${ }^{23}$.

Berdasarkan ruang lingkup permasalahan dan tujuan penelitian maka rancangan penelitian yang digunakan adalah pola pelaksanaan penelitian Quasi Experimental, jenis Nonequivalent Control Group Design yang terdiri dari dua kelompok, yaitu kelompok eksperimen dan kelompok kontrol yang dimaksudkan untuk membandingkan perkembangan kecerdasan logika matematika. Untuk mengetahui kondisi awal kedua kelompok, dilakukan pre test pada kedua kelompok. Setelah itu, kelompok eksperimen diberikan perlakuan (treatment) berupa kegiatan bermain sains sedangkan pada kelompok kontrol tidak diberikan perlakuan. Kemudian dilakukan post test untuk mengetahui kemampuan akhir mengenal bentuk geometri sesudah diberikan perlakuan.

Subyek penelitian ini adalah anak kelompok A TK Islam Insan Kamil Tuban kelas A1 dan A2 yang berjumlah 40 anak yang dibagi menjadi kelas eksperimen dan kelas kontrol. Teknik pengumpulan data penelitian ini menggunakan teknik observasi dan dokumentasi. Observasi merupakan metode pengumpulan data yang menggunakan pengamatan terhadap obyek penelitian ${ }^{24}$. Observasi dalam penelitian ini digunakan untuk mengumpulkan data tentang variabel penelitian yaitu permainan sains dalam mengoptimalkan kecerdasan logika matematika anak yang dikaitkan dengan kegiatan pembelajaran anak usia dini. Adapaun indikator kemampuan logika matematika yang diamati sesuai dengan pedoman kurikulum yang tertuang dalam Peraturan Menteri Pendidikan Nasional No. 58 tahun 2009 tentang Standar Pendidikan Anak Usia Dini ${ }^{25}$ pada tingkat pencapaian perkembangan anak usia 5-6 tahun, yaitu (1) anak mampu mengamati perubahan yang terjadi pada proses percobaan, (2) anak mampu mengenal sebab akibat, (3) anak mampu mengklasifikasikan pada kelompok

\footnotetext{
${ }^{21}$ Sujiono, N. Tampiomas, E. Zainal, R. Metode Pengembangan Kognitif. (Jakarta: Depdiknas, 2007), 156

${ }^{22}$ Sugiyono, Metode Penelitian Kuantitatif, Kualitatif dan R\&D, (Bandung: Alfabeta, 2012), 14

${ }^{23}$ Riyanto, Y. Metodologi Penelitian. (Surabaya: SIC, 2001), 35

${ }^{24}$ Ibid, 96

${ }^{25}$ Peraturan Menteri Pendidikan Nasional no 58 tahun 2009, Standar PAUD
} 
yang sama, (4) anak mampu mengenal konsep ukuran dan konsep bilangan 1-10. Dokumen pada penelitian ini adalah semua kegiatan pada saat awal penelitian sampai dengan akhir penelitian, berupa dokumen berbentuk RKM, RKH, dan langkah-langkah pembelajaran yang telah dirancang dan dilakukan, dan foto kegiatan dan hasil observasi.

Analisis penelitian ini dilakukan secara inferesial statitistik dengan menggunakan statistik parametris. Data yang dianalisis dalam penelitian ini adalah data interval, yaitu dalam bentuk kategori yang memiliki urutan tingkatan dan dapat dikuantitatifkan ${ }^{26}$. Pada statistik parametris, uji hipotesis dilakukan melalui uji prasyarat analisis untuk mengetahui normalitas dan homogenitas data penelitian. Adapaun uji hipotesis yang digunakan dalam penelitian ini adalah ANOVA (Analysis of Variance), dimana uji hipotesis tersebut termasuk dalam uji F.

Analisa data perkembangan kemampuan logika matematika anak dihitung dengan rumus:

Jumlah total skor hasil pengumpulan data

Skor tertinggi tiap item $\mathrm{x}$ jumlah item $\mathrm{x}$

$\mathrm{X} 100 \%$ jumlah responden

Hasil perhitungan rumus skor data kemampuan mengenal bentuk geometri selanjutnya dikategorikan berdasarkan kriteria yang ditetapkan. Kriteria yang ditetapkan (Riduwan, 2009) yaitu:

$\begin{array}{ll}0-20 \% & =\text { sangat lemah } \\ 21 \%-40 \% & =\text { lemah } \\ 41 \%-60 \% & =\text { cukup } \\ 61 \%-80 \% & =\text { kuat } \\ 81 \%-100 \% & =\text { sangat kuat }\end{array}$

\section{HASIL DAN PEMBAHASAN}

Pengamatan yang dilakukan pada kegiatan permainan sains dalam penelitian ini adalah proses belajar mengajar yang dilakukan oleh guru pada kelompok eksperimen dan kelompok kontrol. Pada kelompok kontrol, guru melaksanankan pembelajaran seperti biasa. Sedangkan pada kelompok eksperimen diberikan perlakuan permainan sains.

Berdasarkan hasil pengamatan yang dilakukan pada kelompok eksperimen dan kelompok kontrol dapat diketahui tingkat kemampuan logika matematika anak dalam kegiatan permainan sains dengan melihat pencapaian perkembangan anak yang dilihat dari hasil perolehan kegiatan. Hasil perkembangan kecerdasan logika matematika pada kelompok eksperimen sebelum dan sesudah perlakuan dapat dilihat pada tabel berikut ini:

\section{Tabel 2 Deskripsi Hasil Observasi Awal dan Akhir Perkembangan Kecerdasan Logika Matematika pada Kelompok Eksperimen}

\begin{tabular}{|c|c|c|c|c|}
\hline $\begin{array}{c}\text { Permainan } \\
\text { Sains }\end{array}$ & Kriteria Penilaian & Frekuensi & $\begin{array}{c}\text { Persentase } \\
(\%)\end{array}$ & $\begin{array}{c}\text { Persentase } \\
\text { Peningkatan }\end{array}$ \\
\hline \multirow{2}{*}{$\begin{array}{c}\text { Sebelum } \\
\text { Perlakukan }\end{array}$} & Skor 1 & 0 & \multirow{2}{*}{55} & \multirow{2}{*}{50} \\
\cline { 2 - 3 } & Skor 2 & 16 & & \\
\cline { 2 - 3 } & Skor 3 & 4 & & \\
\hline
\end{tabular}

\footnotetext{
${ }^{26}$ Sujarweni, Statistika Untuk Penelitian. (Yogyakarta: Graha Ilmu, 2012), 20
} 


\begin{tabular}{|c|c|c|c|}
\hline & Skor 4 & 0 & \multirow{2}{*}{} \\
\hline \multirow{3}{*}{$\begin{array}{c}\text { Sesudah } \\
\text { Perlakuan }\end{array}$} & Skor 1 & 0 & \multirow{2}{*}{7} \\
\cline { 2 - 3 } & Skor 2 & 7 & \multirow{2}{*}{70} \\
\cline { 2 - 3 } & Skor 3 & 10 & \\
\cline { 2 - 3 } & Skor 4 & 3 & \\
\hline
\end{tabular}

Berdasarkan tabel di atas, hasil observasi awal menunjukkan hasil sebelum perlakuan kelompok eksperimen bahwa yang mendapat skor 2 sebanyak 16 anak, skor 3 sebanyak 4 anak. Sedangkan persentase perkembangan kecerdasan logika matematika pada observasi awal adalah $55 \%$.

Pada hasil sesudah perlakuan menunjukkan adanya perbedaan dengan hasil sebelum perlakuan yaitu anak yang mendapat skor 2 sebanyak 7 anak, 10 anak mendapat skor 3, dan 3 anak mendapat skor 4. Sedangkan persentase peningkatan perkembangan kemampuan sains pada observasi akhir adalah $70 \%$.

Persentase peningkatan rata-rata sebesar $15 \%$. Hasil tersebut dapat dikatakan bahwa permainan sains berpengaruh terhadap perkembangan kecerdasan logika matematika anak sebesar $15 \%$.

Hasil observasi pekembangan kecerdasan logika matematika pada kelompok kontrol sebelum perlakuan dan sesudah perlakuan dapat dilihat pada tabel 3 berikut ini:

\section{Tabel 3 Deskripsi Hasil Observasi A wal dan Akhir Perkembangan Kecerdasan Logika Matematika Anak pada Kelompok Kontrol}

\begin{tabular}{|c|c|c|c|c|}
\hline $\begin{array}{l}\text { Permainan } \\
\text { Sains }\end{array}$ & Kriteria Penilaian & Frekuensi & $\begin{array}{c}\text { Persentase } \\
(\%)\end{array}$ & $\begin{array}{l}\text { Persentase } \\
\text { Peningkatan }\end{array}$ \\
\hline \multirow{4}{*}{$\begin{array}{l}\text { Sebelum } \\
\text { Perlakukan }\end{array}$} & Skor 1 & 0 & \multirow{4}{*}{52,5} & \multirow{8}{*}{$6,25 \%$} \\
\hline & Skor 2 & 18 & & \\
\hline & Skor 3 & 2 & & \\
\hline & Skor 4 & 0 & & \\
\hline \multirow{4}{*}{$\begin{array}{l}\text { Sesudah } \\
\text { Perlakuan }\end{array}$} & Skor 1 & 0 & \multirow{4}{*}{58,75} & \\
\hline & Skor 2 & 14 & & \\
\hline & Skor 3 & 5 & & \\
\hline & Skor 4 & 1 & & \\
\hline
\end{tabular}

Berdasarkan tabel di atas, hasil observasi awal menunjukkan hasil sebelum perlakuan kelompok kontrol bahwa 18 anak skor 2, dan 2 anak mendapat skor 3. Sedangkan persentase perkembangan kecerdasan logika matematika anak pada observasi awal adalah 52, 5\%.

Pada hasil sesudah perlakuan menunjukkan adanya perbedaan dengan hasil sebelum perlakuan yaitu 14 anak mendapat skor 2, 5 anak mendapat skor 3, dan 1 anak mendapat skor 4. Sedangkan persentase peningkatan perkembangan kecerdasan logika matematika anak pada observasi akhir adalah $58,75 \%$

Persentase peningkatan rata-rata sebesar 6,25\%. Hasil tersebut dapat dikatakan bahwa permainan sains berpengaruh terhadap perkembangan kecerdasan logika matematika anak sebesar $6,25 \%$.

Berdasarkan paparan tersebut di atas, dapat diketahui bahwa ada perbedaan hasil pengukuran dari kelompok tersebut. Hal ini dapat dilihat dari nilai persentase hasil sesudah perlakuan lebih tinggi daripada nilai persentase hasil sebelum perlakuan dari kedua kelompok tersebut. Hal ini berarti bahwa pemberian perlakuan berupa permainan sains pada kelompok eksperimen memberikan pengaruh yang lebih baik terhadap perkembangan kecerdasan logika matematika anak dibandingkan pada kelompok kontrol.

Hasil penelitian dan hasil pengujian hipotesis tersebut membuktikan bahwa pembelajaran melalui permainan sains berpengaruh terhadap perkembangan kecerdasan logika matematika anak. Demikian halnya yang terjadi di TK Islam Insan Kamil Kabupaten Tuban, dari analisa 
deskriptif yang termuat dalam tabel 2 dapat diperoleh dan diketahui bahwa perkembangan kecerdasan logika matematika anak sebelum perlakuan adalah $51,25 \%$ dan sesudah perlakuan meningkat menjadi $70 \%$. Hal ini menunjukkan bahwa hasil pencapaian perkembangan anak setelah mengikuti kegiatan permainan sains, mempunyai pengaruh terhadap perkembangan kecerdasan logika matematika yang lebih baik.

Hasil penelitian ini sesuai dengan pendapat Suyanto, (2005: 84) juga berpendapat bahwa percobaan sederhana yang dilakukan melalui permainan sains akan melatih anak menghubungkan sebab dan akibat dari suatu perlakuan sehingga kemampuan berpikir logis anak dapat terasah ${ }^{27}$.

Pendapat di atas juga dikuatkan oleh pernyataan Sujiono, dkk., (2007: 156) yang menyatakan bahwa kegiatan bermain sains dapat mengembangkan kemampuan sains sederhana yaitu kemampuan eksperimen, observasi, klasifikasi, mengukur, perkiraan, dan komunikasi $^{28}$

\section{KESIMPULAN}

Berdasarkan hasil dan pembahasan di atas, maka kesimpulan yang dapat diambil ialah permainan sains berpengaruh terhadap perkembangan kecerdasan logika matematika pada anak usia dini. Pada hasil analisis pre test kemampuan logika matematika yang dicapai kelompok kontrol yaitu sebesar 52,5\% dan kelompok eksperimen diperoleh $55 \%$. Selanjutnya, setelah dilakukan treatment berupa kegiatan bermain sains, dapat dilihat hasil post test pada kelompok kontrol meningkat sebesar 58,75\%, sedangkan pada kelompok eksperimen juga mengalami peningkatan sebesar $70 \%$. Dari uraian di atas, dapat diketahui bahwa ada perbedaan hasil dari kelompok kontrol dan eksperimen. Hal ini terlihat dari nilai rata-rata hasil post test lebih tinggi daripada nilai rata-rata hasil pre test.

Saran yang dapat diberikan terkait hasil penelitian ini adalah kemampuan logika matematika anak akan berkembang baik apabila pendidik mengembangkan kegiatan pembelajaran yang lebih bervariasi, menarik dan menyenangkan bagi anak, salah satunya dengan permainan sains.

${ }^{27}$ Suyanto, S. Pembelajaran Untuk Anak TK. (Jakarta: Depdiknas, 2005), 84

${ }^{28}$ Sujiono, N. Tampiomas, E. Zainal, R. Metode Pengembangan Kognitif. (Jakarta: Depdiknas, 2007), 156 


\section{DAFTAR PUSTAKA}

Amstrong, Thomas. 2002. Sekolah Sang Juara: Menerapkan Multiple Intelligence di Dunia Pendidikan $2^{\text {nd }}$. Terjemahan. Bandung: Kaifa.

Campbell, linda, Bruce Campbell, dan Dee Dickinson. 2002. Teching and Learning through Multiple Intelligence. Terjemahan. Depok: Inisiasi Press.

Gardner, Howard. 2003. Kecerdasan Majemuk. Batam: Interaksara.

Lwin, May, dkk. 2008. How to Multiply Your Child's Intelligence. Yogyakarta: Penerbit Indeks.

Musfiroh, Tadkiroatun. 2008. Pengembangan Kecerdasan Majemuk. Jakarta: Universitas Terbuka.

Nugraha, A. 2005. Pengembangan Pembelajaran Sains Anak Usia Dini. Jakarta: Danendra.

Peraturan Menteri Pendidikan Nasional no 58 tahun 2009, Standar PAUD

Riduwan. 2009. Rumus dan Data Analisa Statistik. Bandung: Alfabeta

Riyanto, Y. 2001. Metodologi Penelitian. Surabaya: SIC.

Saifullah. 2004. Mencerdaskan Anak (Mengoptimalkan Kecerdasan Intelektual, Emosi dan Spiritual Anak). Jombang: Lintas Media.

Semiawan, Conny. 2002. Belajar dan Pembelajaran dalam Taraf Usia Dini. Jakarta: Prennhalindo.

Sugiyono, 2012. Metode Penelitian Kuantitatif, Kualitatif dan R\&D. Bandung: Alfabeta.

Sujarweni. 2012. Statistika Untuk Penelitian. Yogyakarta: Graha Ilmu

Sujiono \& Sujiono. 2010. Bermain Kreatif Berbasis Kecerdasan Jamak. Jakarta: PT. Indeks.

Sujiono, N. Tampiomas, E. Zainal, R. 2007. Metode Pengembangan Kognitif. Jakarta: Depdiknas.

Suyadi. 2010. Psikologi Belajar Pendidikan Anak Usia Dini. Yogyakarta: PT Pustaka Intan Madani.

Suyanto, S. 2005. Pembelajaran Untuk Anak TK. Jakarta: Depdiknas. 